\title{
Relationship Between Nonalcoholic Fatty Liver and Non High Density Lipoprotein to High Density Lipoprotein Ratio
}

\section{Alkole Bağlı Olmayan Karaciğer Yağlanması ile Yüksek Dansiteli Dışı Lipoprotein/Yüksek Dansiteli Lipoprotein Oranının İlişkisi}

\author{
Recep Alanli ${ }^{1}$ Murat Bulent Kucukay ${ }^{1}$ Kadir Serkan Yalcin ${ }^{1}$
}

${ }^{1}$ Lokman Hekim University, Faculty of Medicine, Department of Internal Medicine, Ankara, Turkey

Address correspondence to: Recep Alanli, Lokman Hekim University, Faculty of Medicine, Department of Internal Medicine, Ankara, Turkey

e-mail: recepalanli@gmail.com

Geliş Tarihi/Received: 26 January 2021 Kabul Tarihi/Accepted: 31 August 2021
$\ddot{O z}$

Amaç: Bu çalışmada, karaciğer yağlanması ile hastaların demografik özellikleri, kan değerleri ve özellikle yüksek dansiteli dışı lipoproteinin yüksek dansiteli lipoproteine oranı (Non-HDL/HDL) arasında bir ilişki olup olmadığını araştırmak hedeflenmiştir.

Hastalar ve Yöntem: Şubat 2020 ile Eylül 2020 tarihleri arasında ultrasonografi ile karaciğer yağlanması saptanan 164 hasta ile saptanmayan 188 hastanın laboratuvar ve ultrasonografi sonuçları prospektif olarak değerlendirildi. Hastaların; boy, ağırlık, karaciğer enzimleri, vitamin d düzeyleri ve lipid değerleri karşılaştırıldı.

Bulgular: Karaciğer yağlanması varlığı ile; ağırık, ALT, AST, vücut kitle indeksi, trigliserid, yüksek dansiteli dışı lipoprotein düzeyleri ve Non-HDL/HDL arasında anlamlı bir ilişki saptandı. Yağlanma şiddeti ile ağırlık, ALT, vücut kitle indeksi ve Non-HDL/HDL arasında anlamlı bir ilişki saptandı. Monosit sayısının yüksek dansiteli lipoproteine oranı ve vitamin D düzeyi ile karaciğer yağlanması varlığı arasında bir ilişki saptanmadı. Non-HDL/HDL oranı ile non-alkolik karaciğer yağlanması arasında ilişki saptanmıştır $(r=0.158)$. Non-HDL/HDL oranının, non-alkolik karaciğer yağlanması tanısındaki pozitif ve negatif prediktif değerleri sırasıyla $\% 56,3$ ve $\% 60,9$ olarak bulunmuştur.

Sonuç: Non-HDL/HDL oranı ile karaciğer yağlanması arasında anlamlı bir ilişki saptandı. Non-HDL/HDL oranı; karaciğer yağlanmasında kullanılabilecek yeni, kullanışı ve kolay ulaşılabilen bir belirteçtir.

Anahtar Kelimeler: Karaciğer yağlanması, nonalkolik, yüksek dansiteli lipoprotein, non-HDL kolesterol Abstract

Aim: The aim of this study was to investigate the relationship between non-alcoholic fatty liver and demographic characteristics, laboratory parameters and predictory non-high density lipoprotein to high density lipoprotein ratio (Non-HDL/HDL).

Patients and Methods: Between February and September 2020, 164 patients who have fatty liver and 188 patients who do not have fatty liver, diagnosed by ultrasonography, were evaluated prospectively. Laboratory (complete blood counts, transaminases, lipid profiles, 25-oh vitamin D3 levels) and ultrasonography findings, body height, body weight and body mass index of patients were compared between groups.

Results: Fatty liver was diagnosed in 164 patients out of 352 participants. There were significant relationships between existence of fatty liver and body weight, alanine aminotransferase aspartate aminotransferase, body mass index, triglyceride levels, non-high density lipoprotein and Non-HDL/HDL. Also relationships between severity of fatty liver and body weight, alanine aminotransferase, body mass index and Non-HDL/HDL ratio were found to be significant. There were no relationship between existence of fatty liver and monocyte to high density lipoprotein ratio and vitamin $D$ levels. Linear regression analysis for Non-HDL/HDL ratio in diagnosis of nonalcoholic fatty liver, revealed a correlation coefficient as $r=0.158$. Positive and negative predictive values for Non-HDL/HDL ratio in diagnosis of nonalcoholic fatty liver were, $56.3 \%$ and $60.9 \%$, respectively.

Conclusion: There is a significant relationship between fatty liver and Non-HDL/HDL. This ratio may be a simple and readily available predictor in patients with fatty liver.

Key words: Fatty liver, nonalcoholic, high density lipoprotein cholesterol, non-high density lipoprotein
Cite this article as: Alanli R, Kucukay MB, Yalcin KS. Relationship Between Nonalcoholic Fatty Liver and Non High Density Lipoprotein to High Density Lipoprotein Ratio. Selcuk Med J 2021;37(3): 251-256
Disclosure: None of the authors has a financial interest in any of the products, devices, or drugs mentioned in this article. The research was not sponsored by an outside organization. All authors have agreed to allow full access to the primary data and to allow the journal to review the data if requested. 


\section{INTRODUCTION}

Nonalcoholic fatty liver (NAFL) is the most frequent chronic liver disease. Prevalence was reported to be as high as 25 to $45 \%$ (1). In animal studies, it was shown that diet based cholesterol was critically important in experimental development of fatty liver (2). Inflammation is an important factor in development of fatty liver. When fat accumulation in hepatocytes increase above normal levels, inflammation will be triggered (3). The relationship between severity of fatty liver and inflammation in hepatocytes were reported previously (4). The relationship between fatty liver and numerous inflammatory markers are still being investigated. Besides those, metabolic syndrome were also accused in pathogenesis of fatty liver (5). Liver biopsy is gold standart in diagnosis of fatty liver. But it is an invazive procedure having complication risks. Ultrasonography was reported to be a suitable diagnostic tool in fatty liver, because of this, usually, ultrasonography is used in diagnosis of fatty liver as a widely available and relatively cheaper method (6).

Monocytes produce cytokines that increase inflammation and oxidative stress (7). High density lipoprotein (HDL), protects endothelium from oxidation of low density lipoprotein (LDL) and also it has antioxidant and anti-inflammatory effects (8). The ratio of monocyte to high density lipoprotein (Monocyte/ HDL) was found to be related to inflammation and severity of oxidative stress (9). This ratio was also reported to be a prognostic predictor in cardiovascular diseases (10). Existence of inflammation was reported to have a role in pathogenesis of fatty liver $(3,4)$. But relationship between monocyte/HDL ratio, as a predictor related to inflammation, and fatty liver was not inspected before. Association between fatty liver and cholesterol levels, especially HDL levels was documented before (11). Non-HDL cholesterol (Non$\mathrm{HDL}$ ) is calculated by substracting HDL from total cholesterol levels. Non-HDL is constituted by very low density lipoprotein, LDL, intermediate density lipoprotein, chylomicrons (ultra low density lipoprotein) and lipoprotein A levels. Non-HDL was reported to be a risk factor for development of NAFL (12). HDL is known for its protective and anti-inflammatory effects, while non-HDL is also known as pro-inflammatory and atherogenic effects (8). For this reason a ratio of non-HDL to HDL was shown to be an inflammatory predictor and it was reported to be related with insulin resistance and metabolic syndrome (13). There are few studies inspecting relationship between fatty liver and Non-HDL to HDL ratio in the literature.
Because of aforementioned reasons, this study was designed to inspect relationship between existence and severity of fatty liver and height, weight and body mass indexes and whole blood count parameters, hepatic transaminases, lipid levels and especially ratios such as monocyte to HDL and NonHDL to HDL in participants.

\section{PATIENTS AND METHODS}

Between February and September 2020, 164 patients diagnosed as having fatty liver and 188 patients in similar age and gender distribution who did not have fatty liver by ultrasonography (control group), total 352 patients who admitted to internal medicine outpatient clinic were included in the study. Laboratory and ultrasonography findings and demographic characteristics of patients were evaluated prospectively. This study was approved by local ethics committee (Approval no: 2020/009 13.02.2020). This study was conducted in compliance with Decleration of Helsinki.

After being evaluated by a ten years experienced radiologist with ultrasonography (GE Voluson 730), participants were divided into study group who had fatty liver and control group who did not have fatty liver. Age, gender, height, weight and body mass indexes (BMI), plasma alanine aminotransferase (ALT), plasma aspartate aminotransferase (AST), whole blood counts including neutrophil, lymphocyte and monocyte counts and mean platelet volumes (MPV), 25-hydroxy vitamin d3, HDL, LDL, triglyceride, total cholesterol and non-HDL levels and ratios; monocyte to HDL and Non-HDL to HDL of all participants were recorded and data of study and control groups were compared. Patients who had fatty liver were also subgrouped into two; mild (grade 1) and advanced (grade 2 and 3 ), according to grades of fatty liver. These two subgroups were also compared with parameters mentioned above. BMI was calculated by division of body weight in kilograms to square of height in meters.

\section{Ultrasonographic evaluation of fatty liver were made upon following criteria:}

- Patients who do not have fattly liver; Echogenicity of liver is lower than kidneys

- Patients who do have fatty liver;

-Mild fatty liver; echogenity of liver is slightly increased but differentiation of periportal vascularity and distinction of diaphragmatic echogenity from liver echogenity is possible

-Advanved fatty liver; echogenity of liver is increased 
medium to severe degree and periportal vascularity and/or diaphragmatic echogenity cannot be distinguished from liver echogenity (14).

Metabolic syndrome existence was evaluated by National Cholesterol Education Program Adult Treatment Panel III criteria. According to those criteria, metabolic syndrome was diagnosed in patients having three of following conditions; Obesity, hyperglycemia, hypertension, triglycerides above $150 \mathrm{mg} / \mathrm{dL}$, HDL below $50 \mathrm{mg} / \mathrm{dL}$ in women and below $40 \mathrm{mg} / \mathrm{dL}$ in men. Obesity was evaluated by BMI parameter, as recommended in Obesity Diagnosis and Treatment Guide of Turkish Society of Endocrinology and Metabolism (15). Patients having liver diseases and malignancies, consuming alcohol, using anti-hyperlipidemic drugs (statins, fibrates) and patients under 18 years old (since they were admitting to pediatrics clinics) were excluded from study. Blood samples were obtained after 12 hours of fasting. Whole blood counts were analyzed in Sysmex XN-1000 (USA) device. ALT, AST, LDL, $\mathrm{HDL}$, triglycerides and total cholesterol levels were analyzed by Roche Hitachi Cobas 501 (Switzerland) device. 25-hydroxy vitamin $\mathrm{D}$ levels were analyzed by Roche Hitachi Cobas 601 (Switzerland) device with liquid chromatography method. SPSS for Windows 25.0 statistical software package (SPSS Inc., Armonk,
NY, USA) was used for statistical analysis of the data. Data distributions or normality tests were evaluated by Shapiro-Wilk test. Data were presented as mean \pm standard deviation for normal distributed variables, as median (minimum-maximum) for non-normal distributed variables. The comparisons between groups were evaluated by independent t-test and Mann-Whitney $U$ tests when t-test was not applicable. $P$ Values below 0.05 were considered significant. In the receiver operator characteristics curve (ROC), the area under the curve was used to determine diagnostic cut-off values for Non-HDL/HDL ratio in predicting nonalcoholic fatty liver.

\section{RESULTS}

NAFL was diagnosed in 164 patients, while 188 patients had normal ultrasonography findings. There were significant relationship between existence of fatty liver and body weight, body mass index, ALT, AST, triglyceride levels, non-HDL. Non-HDL to HDL ratio was significantly higher in NAFL group compared to control group. There were no relationship between existence of fatty liver and monocyte to high density lipoprotein ratio and vitamin d levels. Comparison of demographic characteristics and laboratory findings of patients in NAFL and control group was shown in Table 1.

Table 1. Comparison of demographic characteristics and laboratory findings of patients according to existence of nonalcoholic fatty liver

\begin{tabular}{|c|c|c|c|}
\hline Parameter & Have fatty liver & Do not have fatty liver & p Value \\
\hline Age (years) & $55.33 \pm 15.19$ & $50.29 \pm 20.61$ & 0.013 \\
\hline Gender(Male/Female) & $79(48.1 \%)-85(51.9 \%)$ & $76(46 \%)-89(54 \%)$ & 0.627 \\
\hline Height (meter) & $1.66 \pm 0.08$ & $1.66 \pm 0.09$ & 0.990 \\
\hline Body weight (kilograms) & $89.53 \pm 16.20$ & $70.63 \pm 12.44$ & $<0.001$ \\
\hline $\mathrm{ALT}^{*}(\mathrm{IU} / \mathrm{L})$ & $32.82 \pm 38.75$ & $20.14 \pm 15.23$ & $<0.001$ \\
\hline $\mathrm{AST}^{\dagger}(\mathrm{IU} / \mathrm{L})$ & $28.32 \pm 29.43$ & $19.06 \pm 9.53$ & $<0.001$ \\
\hline $\mathrm{HDL}^{\ddagger}(\mathrm{mg} / \mathrm{dL})$ & $42.57 \pm 13.33$ & $45.33 \pm 13.97$ & 0.068 \\
\hline Neutrophil count $\left(10^{9} / \mathrm{L}\right)$ & $5.46 \pm 2.73$ & $5.00 \pm 3.01$ & 0.154 \\
\hline Lymphocyte count (10\%/L) & $2.23 \pm 0.86$ & $2.09 \pm 0.80$ & 0.129 \\
\hline Platelet count $\left(10^{9} / \mathrm{L}\right)$ & $276.00 \pm 94.35$ & $258.00 \pm 77.97$ & 0.061 \\
\hline Mean platelet volume (fL) & $10.16 \pm 0.94$ & $10.20 \pm 1.03$ & 0.702 \\
\hline Monocyte count $(109 / \mathrm{L})$ & $0.66 \pm 0.33$ & $0.66 \pm 0.30$ & 0.981 \\
\hline 25-hydroxy vitamin $D(\mathrm{ng} / \mathrm{mL})$ & $15.33 \pm 11.61$ & $17.65 \pm 12.94$ & 0.236 \\
\hline Body mass index & $32.12 \pm 5.89$ & $25.54 \pm 5.16$ & $<0.001$ \\
\hline Monocyte/HDLf ratio & $0.01 \pm 0.01$ & $0.01 \pm 0.01$ & 0.634 \\
\hline Total cholesterol (mg/dL) & $176.09 \pm 49.65$ & $165.07 \pm 47.84$ & 0.052 \\
\hline LDL§ cholesterol (mg/dL) & $98.20 \pm 38.22$ & $96.25 \pm 36.77$ & 0.658 \\
\hline Triglycerides $(\mathrm{mg} / \mathrm{dL})$ & $176.10 \pm 105.18$ & $129.78 \pm 91.88$ & $<0.001$ \\
\hline Non-HDL Cholesterol (mg/dL) & $133.59 \pm 46.07$ & $120.22 \pm 43.78$ & 0.010 \\
\hline Non-HDL/HDL ratio & $3.41 \pm 1.50$ & $2.90 \pm 1.30$ & 0.002 \\
\hline
\end{tabular}

\footnotetext{
* Plasma Alanine aminotransferase

† Plasma Aspartate aminotransferase

$\ddagger$ High density lipoprotein cholesterol

$\S$ Low density lipoprotein cholesterol
} 
Table 2. Comparison of demographic characteristics and laboratory findings of patients according to severity of nonalcoholic fatty liver

\begin{tabular}{|c|c|c|c|}
\hline Parameter & Mild fatty liver & Advanced fatty liver & p Value \\
\hline$\overline{\text { Age (years) }}$ & $56.91 \pm 16.55$ & $53.68 \pm 14.33$ & 0.185 \\
\hline Gender(Male/Female) & $36(42.8 \%)-48(57,2 \%)$ & $43(53.7 \%)-37(46.3 \%)$ & 0.162 \\
\hline Height (meter) & $1.66 \pm 0.08$ & $1.67 \pm 0.09$ & 0.800 \\
\hline Body weight (kilograms) & $84.82 \pm 13.12$ & $94.22 \pm 17.80$ & $<0.001$ \\
\hline $\mathrm{ALT}^{*}(\mathrm{IU} / \mathrm{L})$ & $24.33 \pm 26.83$ & $41.53 \pm 46.49$ & 0.004 \\
\hline $\mathrm{AST}^{+}(\mathrm{IU} / \mathrm{L})$ & $25.20 \pm 31.59$ & $31.48 \pm 26.60$ & 0.180 \\
\hline $\mathrm{HDL}^{\ddagger}(\mathrm{mg} / \mathrm{dL})$ & $44.63 \pm 15.13$ & $40.32 \pm 10.71$ & 0.038 \\
\hline Neutrophil count $\left(10^{9} / \mathrm{L}\right)$ & $5.44 \pm 2.92$ & $5.44 \pm 2.54$ & 0.983 \\
\hline Lymphocyte count $\left(10^{\%} / \mathrm{L}\right)$ & $2.16 \pm 0.97$ & $2.29 \pm 0.72$ & 0.340 \\
\hline Platelet count $\left(10^{\%} / \mathrm{L}\right)$ & $281.73 \pm 109.72$ & $269.7 \pm 74.44$ & 0.414 \\
\hline Mean platelet volume ( $\mathrm{fL}$ ) & $10.12 \pm 1.01$ & $10.2 \pm 0.88$ & 0.616 \\
\hline Monocyte count $\left(10^{9} / \mathrm{L}\right)$ & $0.63 \pm 0.25$ & $0.69 \pm 0.39$ & 0.279 \\
\hline 25-hydroxy vitamin D $(\mathrm{ng} / \mathrm{mL})$ & $14.10 \pm 8.4$ & $17.00 \pm 14.84$ & 0.268 \\
\hline Body mass index & $30.48 \pm 4.63$ & $33.77 \pm 6.59$ & $<0.001$ \\
\hline Monocyte/HDL $\ddagger$ ratio & $0.16 \pm 0.01$ & $0.19 \pm 0.01$ & 0.116 \\
\hline Total cholesterol (mg/dL) & $179.96 \pm 58.07$ & $171.67 \pm 37.02$ & 0.316 \\
\hline LDL§ cholesterol (mg/dL) & $101.90 \pm 44.05$ & $93.69 \pm 29.43$ & 0.219 \\
\hline Triglycerides (mg/dL) & $163.48 \pm 108.11$ & $189.93 \pm 100.16$ & 0.124 \\
\hline Non-HDL Cholesterol (mg/dL) & $135.14 \pm 52.51$ & $131.97 \pm 1.57$ & 0.680 \\
\hline Non-HDL/HDL ratio & $3.26 \pm 1.42$ & $3.6 \pm 1.57$ & 0.170 \\
\hline
\end{tabular}

*Plasma Alanine aminotransferase

† Plasma Aspartate aminotransferase

$\ddagger$ High density lipoprotein cholesterol

Low density lipoprotein cholesterol

NAFL diagnosed patients was distributed into mild and advanced subgroups. Eighty four (51.2\%) patients had mild, $80(48.8 \%)$ patients had advanced NAFL. Relationship between severity of fatty liver and body weight, ALT, BMI and Non-HDL to HDL ratio were found to be significant. Comparison of severity of NAFL subgroups by demographic characteristics

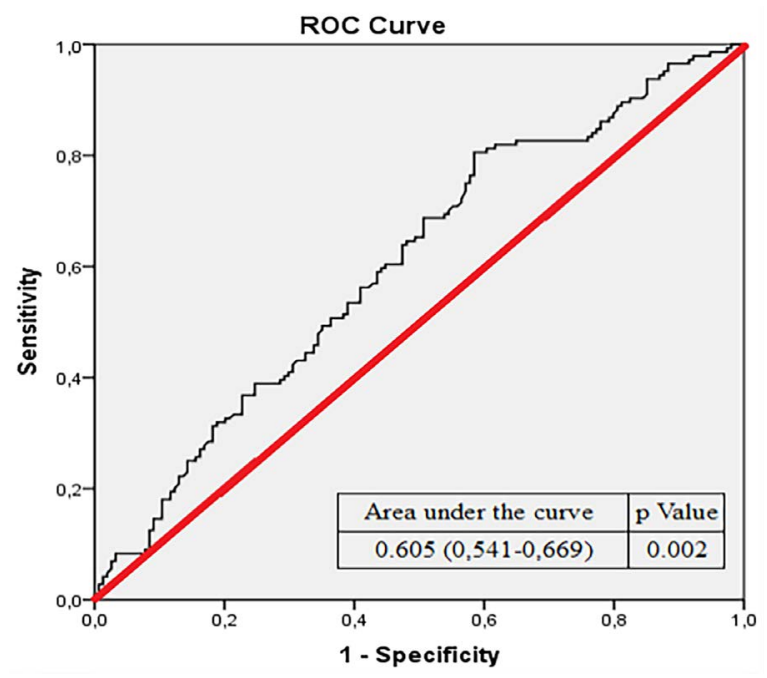

Figure 1. Receiver operating characteristics curve analysis for Non-HDL to HDL ratio in NAFL and laboratory parameters was shown in Table 2 .

In study group 120 (73.1\%) patients had metabolic syndrome while $44(26.9 \%)$ had no metabolic syndrome $(p=0.001)$. In control group $168(83.3 \%)$ patients had metabolic syndrome while $20(10.7 \%)$ had no metabolic syndrome $(p<0.001)$. This study inspected 352 participants, $165(46.8 \%)$ were male and 187 $(53.2 \%)$ were female. Mean age of participants were $53.73 \pm 17.99(49.14 \pm 17.19$ in males, $57.79 \pm 17.75$ in females). NAFL was diagnosed in $79(48.1 \%)$ males and in $85(51.9 \%)$ females, while $86(\% 45.7)$ males and 102 (\%54.3) females did not have NAFL. In order to determine the effectiveness of Non-HDL/HDL ratio to predict nonalcoholic fatty liver, ROC curve analysis was done and shown in Figure 1. Optimal cut-off value for Non-HDL/HDL ratio was 2.3 (81\% sensitivity, $42 \%$ specificity). Linear regression analysis for Non-HDL/ $\mathrm{HDL}$ in diagnosis of nonalcoholic fatty liver, revealed a correlation coefficient as $r=0.158(p=0.003)$.

\section{DISCUSSION}

According to the results of this study there was a significant relationship between fatty liver and nonhigh density lipoprotein to high density lipoprotein ratio. This ratio may be a simple and readily available predictor in patients with fatty liver.

Dyslipidemia was reported as an effective factor in 
pathogenesis of NAFL (11). It was reported that obesity and insulin resistance resulted in increase in NonHDL and decrease in HDL levels (16). In concordance with this, Non-HDL to HDL ratio was used to predict insulin resistance and metabolic syndrome (13). Obesity and existence of insulin resistance are two main factors in development of metabolic syndrome. Metabolic syndrome was reported as a risk factor for NAFL development (1). In this reported study, there is a significant relationship between existence of NAFL and metabolic syndrome. Non-HDL contains all lipoproteins with apo-B. Non-HDL to HDL ratio is reported to be better in predicting proatherogenic and anti-atherogenic lipoprotein balance and lipid dysregulation. Also this ratio is better in predicting NAFL development than Non-HDL (17). Non-HDL to HDL ratio was also reported to more effective in determining cardiovascular diseases than Non-HDL (18). In a study reported from China, 2717 patients were followed for mean 1.6 years and Non-HDL to HDL ratio was found to be related to new development of NAFL (17). Similarly, this study reports a relationship between Non-HDL to HDL ratio and NAFL.

Patients with NAFL were reported to have lower HDL and higher triglyceride levels (19). In a study with 18061 patients, triglyceride to HDL ratio was found to be related to NAFL. This situation was explained by existence of insulin resistance in those patients (20). Both triglyceride and HDL levels are predictive parameters for metabolic syndrome thus, relationship of increased triglyceride to HDL ratio with NAFL may be reasonable in these patients. Presented study reveals a significant relationship between NAFL and triglyceride levels. HDL levels in study group was higher than control group but this was not statistically significant. Non-HDL was found to be related to NAFL development (12). This study also reveals significant relationship between NAFL and non-HDL. But this relationship was weaker compared to non-HDL to HDL ratio, similarly to a previously reported study (17). Monocytes have pro-inflammatory and prooxidant effects, contrarily HDL has exactly opposite effects (21). The ratio of monocytes to HDL was reported to be related with systemic inflammation (22). Monocyte to HDL ratio was also found to be related with risk of cardiovascular disease development and metabolic syndrome $(10,23)$. Role of existence of inflammation in pathogenesis of NAFL was previously reported $(3,4)$. But relationship between monocyte to HDL ratio, as an inflammatory marker, and NAFL was not previously researched. In this study, the relationship between monocyte to $\mathrm{HDL}$ ratio and NAFL was inspected and found to be insignificant. Transaminases, AST and ALT are two markers reflecting inflammation and injury in liver and they are found to be increased in blood serum. Especially ALT is a predictor in NAFL (24). This study reports that AST and ALT levels are related to NAFL. Additionally, it was also demonstrated that ALT levels, but not AST levels, were found to be significantly increased when severity of steatosis increased.

Relationship between body weight, obesity and NAFL is well known. A study documented the relationship between body weight and NAFL (25). Concordantly, this study also reports significant relationship between NAFL and body weight and BMI. Also, in advanced NAFL subgroup body weight and BMI were significantly higher compared to mild NAFL subgroup. There are studies reporting association between vitamin d deficiency and non-alcoholic fatty liver $(26,27)$. In this reported study vitamin d levels were lower in non-alcoholic fatty liver group but this finding was not statistically significant. There is still need for further studies about this subject. There are some limitations in this study. Steatosis was evaluated by only ultrasonography, liver biopsy was not performed. Liver biopsy was not preferred since it is a definitively invasive diagnostic procedure for patients. Also, since this study was a single centered study, results may not represent whole population.

In conclusion; there is a significant relationship between non-HDL to HDL ratio and NAFL, according to the results of this presented study. The ratio of non-HDL to HDL may be a novel, useful and easily applicable marker in predicting NAFL. Relationship between monocyte to HDL and NAFL was not significant in this study and more studies are required to inspect this relationship in detail.

Acknowledgements: Author of this study thank to Dr. Seda Akyol for evaluation of ultrasonographies, Dr. Gultekin Celik for laboratory works and Mr. Fatih Acıkgoz for statistical evaluation and advices.

Conflict of interest: Authors declare that there is no conflict of interest between the authors of the article.

Financial conflict of interest: Authors declare that they did not receive any financial support in this study.

Address correspondence to: Recep Alanli, Lokman Hekim University, Faculty of Medicine, Department of Internal Medicine, Ankara, Turkey

e-mail: recepalanli@gmail.com

Mobile Phone Number: +90 5066885007 


\section{REFERENCES}

1. Lonardo A, Bellentani S, Argo CK, et al. Epidemiological modifiers of non-alcoholic fatty liver disease: Focus on highrisk groups. Digestive and Liver Disease 2015;47(12):9971006.

2. Farrell GC, van Rooyen D. Liver cholesterol: Is it playing possum in NASH? American Journal of PhysiologyGastrointestinal and Liver Physiology 2012;303(1):G9-11.

3. Tessari P, Coracina A, Cosma A, et al. Hepatic lipid metabolism and non-alcoholic fatty liver disease. Nutrition, Metabolism and Cardiovascular Diseases 2009;19(4):291302.

4. Fang J, Ji Y, Zhang P, et al. Hepatic IRF2BP2 mitigates nonalcoholic fatty liver disease by directly repressing the transcription of ATF3. Hepatology 2020;71(5):1592-608.

5. Paschos P, Paletas K. Non alcoholic fatty liver disease and metabolic syndrome. Hippokratia 2009;13(1):9-19.

6. Kamali L, Adibi A, Ebrahimian S, et al. Diagnostic performance of ultrasonography in detecting fatty liver disease in comparison with fibroscan in people suspected of fatty liver. Adv Biomed Res 2019;8:69.

7. Ancuta P, Wang J, Gabuzda D. CD16+monocytes produce IL-6, CCL2, and matrix metalloproteinase-9 upon interaction with CX3CL1-expressing endothelial cells. Journal of Leukocyte Biology 2006;80(5):1156-64.

8. Canpolat U, Çetin EH, Cetin S, et al. Association of monocyteto-HDL cholesterol ratio with slow coronary flow is linked to systemic inflammation. Clinical and Applied Thrombosis/ Hemostasis 2015;22(5):476-82.

9. Akboga MK, Balci KG, Maden O, et al. Usefulness of monocyte to HDL-cholesterol ratio to predict high SYNTAX score in patients with stable coronary artery disease. Biomarkers in Medicine 2016;10(4):375-83.

10. Cetin MS, Ozcan Cetin EH, Kalender E, et al. Monocyte to HDL cholesterol ratio predicts coronary artery disease severity and future major cardiovascular adverse events in acute coronary syndrome. Heart, Lung and Circulation 2016;25(11):1077-86.

11. Fisher E, Cohen D. Lipoprotein metabolism, dyslipidemia, and nonalcoholic fatty liver disease. Seminars in Liver Disease 2013;33(04):380-8.

12. Zelber Sagi S, Salomone F, Yeshua H, et al. Non-highdensity lipoprotein cholesterol independently predicts new onset of non-alcoholic fatty liver disease. Liver International 2013;34(6):e128-35.

13. Kim SW, Jee JH, Kim HJ, et al. Non-HDL-cholesterol/HDLcholesterol is a better predictor of metabolic syndrome and insulin resistance than apolipoprotein B/apolipoprotein A1. International Journal of Cardiology 2013;168(3):2678-83.

14. Rumack CM, Levine D. Diagnostic ultrasound E-Book. 2-Volume Set (5th Edition). Philedelphia, PA: Elsevier Health Sciences 2018:91-92.
15. Türkiye Endokrinoloji ve Metabolizma Derneği (2020). Obezite Tani ve Tedavi Kılavuzu (10 Ocak 2021 tarihinde https://temd. org.tr/admin/uploads/tbl_kilavuz/20190506163904-2019tbl_ kilavuz5ccdcb9e5d.pdf web adresinden ulaşılmıştır).

16. Fon Tacer K, Rozman D. Nonalcoholic fatty liver disease: Focus on lipoprotein and lipid deregulation. Journal of Lipids 2011;2011:1-14.

17. Wang $\mathrm{K}$, Shan $\mathrm{S}$, Zheng $\mathrm{H}$, et al. Non-HDL-cholesterol to $\mathrm{HDL}$-cholesterol ratio is a better predictor of new-onset nonalcoholic fatty liver disease than non-HDL-cholesterol: A cohort study. Lipids in Health and Disease 2018;17(1):196.

18. Taskinen MR, Barter PJ, Ehnholm C, et al. Ability of traditional lipid ratios and apolipoprotein ratios to predict cardiovascular risk in people with type 2 diabetes. Diabetologia 2010;53(9):1846-55.

19. Speliotes EK, Massaro JM, Hoffmann U, et al. Fatty liver is associated with dyslipidemia and dysglycemia independent of visceral fat: The Framingham heart study. Hepatology 2010;51(6):1979-87.

20. Fan N, Peng L, Xia Z, et al. Triglycerides to high-density lipoprotein cholesterol ratio as a surrogate for nonalcoholic fatty liver disease: A cross-sectional study. Lipids in Health and Disease 2019;18(1):39.

21. Inonu Koseoglu $H$, Pazarli AC, Kanbay A, et al. Monocyte count/HDL cholesterol ratio and cardiovascular disease in patients with obstructive sleep apnea syndrome: A multicenter study. Clinical and Applied Thrombosis/Hemostasis 2016;24(1):139-44.

22. Cimen S, Dursun M, Sulukaya M, et al. Could the monocyte/ $\mathrm{HDL}$ cholesterol ratio be an early marker of erectile dysfunction? The Aging Male 2019;1-6.

23. Uslu AU, Sekin Y, Tarhan G, et al. Evaluation of monocyte to high-density lipoprotein cholesterol ratio in the presence and severity of metabolic syndrome. Clinical and Applied Thrombosis/Hemostasis 2017;24(5):828-33.

24. Schindhelm RK, Dekker JM, Nijpels G, et al. Alanine aminotransferase predicts coronary heart disease events: A 10-year follow-up of the Hoorn Study. Atherosclerosis 2007;191(2):391-6.

25. Woo Baidal JA, Lavine JE. The intersection of nonalcoholic fatty liver disease and obesity. Science Translational Medicine 2016;8(323):323rv1.

26. Gad Al, Elmedames MR, Abdelhai AR, et al. The association between vitamin $D$ status and non-alcoholic fatty liver disease in adults: A hospital-based study. Egypt Liver Journal 2020;10(25):1-8.

27. Liu S, Liu Y, Wan B, et al. Association between vitamin D status and non-alcoholic fatty liver disease: A populationbased study. J Nutr Sci Vitaminol (Tokyo) 2019;65(4):303-8. 